\title{
The U.Porto e-learning café: Learning Spaces and the Path of Self Education
}

\author{
Maria Aguiar Pinto \\ Reitoria Universidade do Porto \\ Porto, Portugal \\ mariapinto@reit.up.pt
}

\author{
Lígia Maria Ribeiro \\ Pro-Rector, University of Porto \\ Porto, Portugal \\ $\underline{\operatorname{lmr} \text {,reit.up.pt }}$
}

\begin{abstract}
In the European Higher Education Area "learning" is a key word as well as individual responsibility and engagement with self education. Universities are facing demanding challenges mainly due to the rising of life-longlearning needs, to significant cuts on public budgets and to strong pressures to achieve increasing levels of excellence both in education and research. In a globalized society where information and communication technologies (ICT) play a major role, employers require that college graduates be excellent in communication and in the use of information, be able to think creatively, innovate, cooperate and compete across borders.
\end{abstract}

At the University of Porto (U.Porto) we believe that the spatial configuration of learning spaces and the facilities and initiatives they accommodate may be rather important to provide effective environments for learning and mingling, motivating students to become more knowledgeable and equipped with the interdisciplinary and high level skills the 21 st century society requires.

In these contexts information technologies are important tools for creating and promoting innovative students environments.

Keywords-Learning spaces; virtual environments; technologies enriched learning spaces.

\section{INTRODUCTION}

U.Porto is committed to offering its students new dynamic learning spaces to promote the exchange of knowledge, the sharing of experiences, and to stimulate interdisciplinary innovation.

U.Porto is the largest Portuguese higher education institution, with a student community of more than thirty one thousand at its 14 autonomous faculties and business school [1]. The University recognizes the relevance of ICT for the overall performance of the institution and in creating unity in diversity. It is no surprise thus that U.Porto has encouraged the development of inclusive hybrid spaces for learning, socialization and leisure, integrating some important ICT functions. The first e-learning café in Portugal was opened by U.Porto in January 2008. It is located on the largest of the three campus of the University, available for all higher education students and alumni, even if they are not or were not U.Porto students.

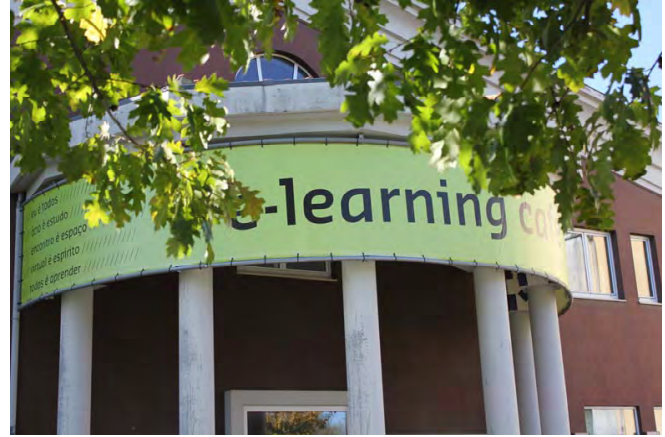

Figure 1: the e-learning café of UPorto

The success achieved with this initiative lead the University to consider the launching of a second space of this kind. This second e-learning café has its preliminary project already approved by the rector team and is planned for the second biggest campus in connection with the University botanical garden. This second e-learning café is expected to be launched in 2013. The e-learning café is not just a space strongly equipped with technology for students and teachers to study and socialize; it is much more than that! A very rich program of workshops, concerts, exhibitions, and other activities is carefully planned to achieve the sharing of knowledge and the objectives foreseen.

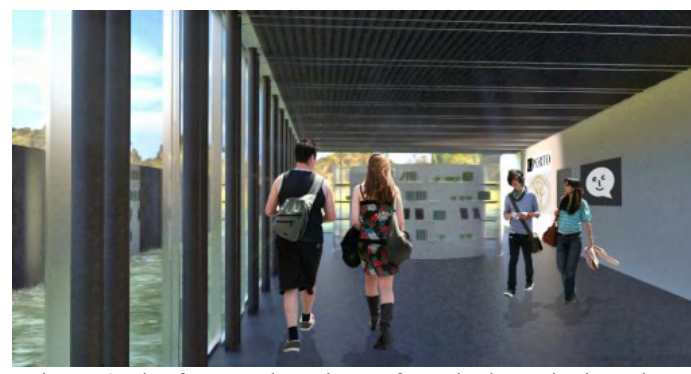

Figure 2: the future e-learning café at the botanical garden 
Students from engineering courses are regular followers at the e-learning café and many have active roles as mentors. They easily contribute in solving problems and sharing ideas as well as proposing new facilities and activities for this space. We frequently observe students sharing and debating ideas with different curriculum backgrounds. The students are also interested in different cultural activities, suggesting and participating in concerts, workshops and exhibitions. Offering a wide variety of different stimulus is crucial for the development of an open mind. As Bruce Mau refers [5] "An environment rich in evocative objects--whether it's a classroom or a museum--triggers active learning by letting students pick what to engage with".

In this communication we will present some of the activities developed with the students at the e-learning café, to stimulate interdisciplinary thinking, intellectual curiosity, team work and cooperation.

\section{EXAMPLES OF ACTIVITIES LAUNCHED IN 2012}

E-learning café of Asprela has a nontraditional schedule, it is open all year around, 365 days, and throughout the year the opening hours are adapted to the needs of the users. Regular hours are the seven days of the week, from 10 a.m. to 4a.m., but during examinations periods is always open, seven days a week - 24 hours, having security all night. It is mainly a place to study were the design of the furniture and the arrangements of tables are cozy and relaxing. Nevertheless this space is also a place to communicate and socialize. To enhance these soft skills, several activities were proposed as the examples above mentioned. All the activities are planned for the beginning of the semesters, the time for excellence when students have more time to do other things, so they can take advantages of the e-learning café program. All the activities are free of charge and open to all the academic community. The only limitation is the space available, as the areas were activities usually take place are not very large.

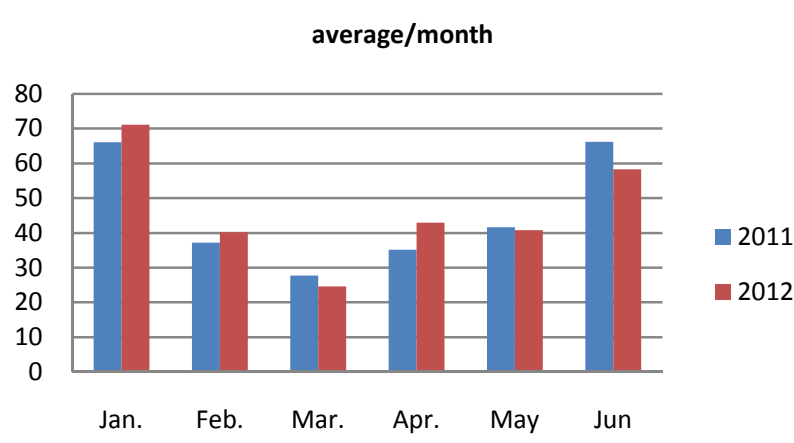

Figure $3-1^{\text {st }}$ semester occupation

\section{"Mostra-Te" initiative}

"Mostra-Te" means in Portuguese "show yourself" or "get out of the box". This initiative has as main objective to bring to the e-learning café the work developed by research departments in the University, which in many cases are not well known by the students. In the course of this initiative several different startups and research groups have been invited to present their work in a very concise and appellative way to catch student's eyes on the subjects, for them to understand the importance of working in multidisciplinary teams and to visualize new ways to build up innovation, opening their horizons.

On the first semester of 2012, three different initiatives took place; all related with new and creative ideas, involving different areas of knowledge and that ended up on very interesting projects. They involved 3 different startup's: Around Knowledge; Sem+nem - moving houses; Ideia.m.

The number of students that participated in these different sessions was very variable and all the sessions had live streaming options as well. The sessions took place in the multimedia room that has a capacity of 25 seats.

One of the ideas of the "Mostra-Te" project is to bring researchers and creatives close to the students by motivating an informal conversation, so that students feel comfortable to put questions, interact and learn with the experience of others.

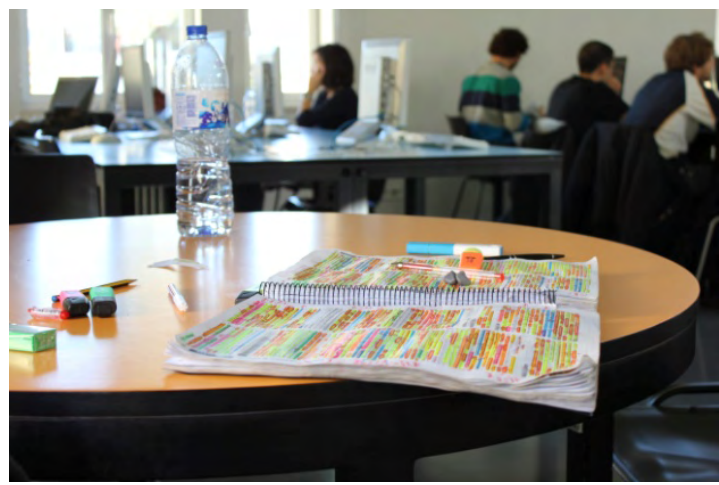

Figure 4 - Sharing knowledge and debating ideias

\section{1) Around Knowledge(AK)}

Around Knowledge is a Portuguese company created by three university researchers aiming to cross the bridge between the academic world and industry. AK is well established in the mobile application and wireless market and participates in the MIT Portugal Program - Innovation \& Entrepreneurship Initiative (MPP-IEI) start-up. AK has nowadays a multidisciplinary team composed by software and hardware engineers, designers and marketing specialists.

We invited $\mathrm{AK}$ to do a small presentation at e-learning café and, for the event the company developed a specific application for smart phones, the e-CUP Mobile. This has been very valued by the students, offering them new ways to access the information they need from their mobile devices.

Around Knowledge also developed, just for the presentation day, a new game, a car race, that was projected on the wall of the multimedia room that students could play with their Smartphone's. All the scores were registered on the e-learning café facebook page.

The dynamic created by all interactions between the people from $\mathrm{AK}$ and the students with the help of all the 
gadgets and technology available, was very important for the participants.

\section{2) Sem+nem - moving houses}

The concept "casas em movimento" (moving houses), presented at Solar Decathlon in Spain, is based on the sun's potential, the source of light and heat, as well as on the management and mutation of spaces in the house, answering everyday life needs on the 21 st century. A dwelling that interacts with the environment and solar luminosity variations, recreates at each moment a new interior and exterior space, adapting itself to the daily routine, changes its appearance during the day, follows the sun's course, and feeds from it. The project takes place on the vanguard of Architecture and Engineering, looking to sustainability and to the construction of a new future, pursuing the concept of "house as a living element", adapting and offering the best quality of the inhabitant's life.

\section{3) Ideia.m}

Ideia.m is a new company created as a result of an academic project in research and development of musical instruments. Ideia.m is specialized in advanced materials and technologies, mainly related with composite materials. The company works on this musical project and expanded the activity to other areas, such as automotive, laboratorial and furniture components design and production. At the elearning café Ideia.m performed a very interactive presentation, explaining how the idea of creating the company started as a result of a final project in one of the courses in the last year of the university. An example of the guitar developed by the company was exhibited at the e-learning café before and after the presentation. During the presentation some of the participants were able to play and manipulate de guitar.

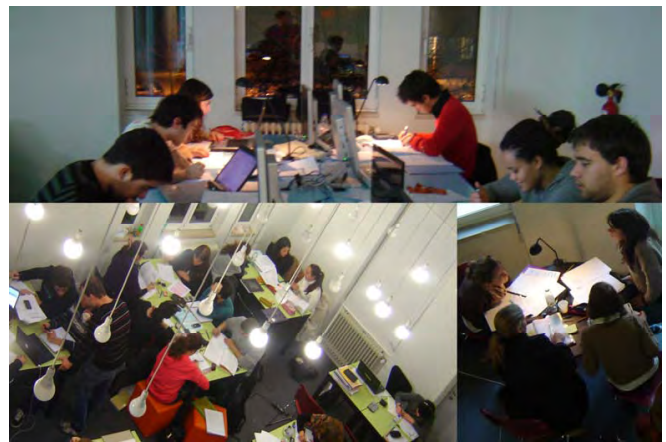

Figure 5: different aspects of the occupation

\section{Voce Sabe Mesmo de Automóveis Antigos}

This activity took place last year and brought to the elearning café many students that had never been there before.

To promote the interaction between the schools of Engineering of the U.Porto and the classical cars community in Porto region, a contest was organized at the e-learning to evaluate the degree of knowledge and expertize in classic cars background. The first challenge was related to Jaguar cars, where a quiz with 20 questions was prepared. The participants were in majority engineering students, but also members of some classic cars clubs, and general fans and automotive entusihasts. It was presented and classified under the portuguese academic evaluation system as if an important exam was taking place, giving the necessary academic atmosphere. This evening event was presented in the elearning-café which perfectly established one of its roles: establishing links between academic activities and external companies. The event was sponsored by the Portuguese Jaguar Cars dealer, speciallized automotive bookshop Ascari and the Classic Cars restoration company Good Old Times.

\section{Engenho e Arte - Skilled Art Project}

This is a project on interface research and development and associated strategies for the creation and maintenance of transdisciplinary communities of knowledge. Telematic communication between physical spaces, for virtual interaction in the context of e-learning, is its main focus.

Strategies were developed to join students coming from different disciplines in order to create new transdisciplinary knowledge. This strategies were applied and developed in actions/tests by ARTSHARE at the e-learning café, U.Porto., and at the mobile platform e-learning Nomad, University of Aveiro.

The project has had a close collaboration of the Planetary Collegium, an international strategic partner that provides most of the means for the promotion and communication of the new knowledge acquired.

Several activities were organized, with different objectives and different impact on the intervenients as well as in the space.

Skilled Surprise - A project that emerges from a spontaneous idea that came up during an informal conversation. The project involved several researchers from the area of arts and multimedia, creating environments for the share of knowledge from the creation of content in real time. An analysis of the space and its users was performed and having in mind the preferences of the students, a setup was prepared. On a specific day, the students that were studying in the multimedia room were surprised with the projection of some questions projected on the table. An interaction between the different tables and different content projected was naturally created. A wide range of different ways of communication was available to the students, video, sound, text and graphic. The collection of different answers was them collected and instantly created a unique visual and audio composition that was projected on the wall.

\section{Opening Reading Frames}

It is a meta-project that aims to develop collective forms of creation/improvisation in multiuser interactive spaces. It builds up from knowledge that has been acquired in projects such as Walking on Earth or CaDaReMi and aims to expand those boundaries and create new challenges that will materialize the idea of interactive spaces as agents of 
developing relationships between individuals and catalyses of interpersonal communication through sensorial artistic experiences. The designation Opening Reading Frames, is related to the capacity to produce different outputs according to the way different agents interact on a code or topology. The construction of poetic narratives (Story Tailor), the musical exploration of audio information (SurfIN), the construction vocal elements resulting from the hybridization between music and sound poetry (Soneme) or the construction of multitrack/multiuser sequencers. The common idea between these possibilities is the fact that the visual and sound output depends on the relationships that the agents (the users) develop between themselves, which is to say that the artist product emerges as a consequence of the interaction between the users.

By presenting this kind of activities at the e-learning café we aim to encourage students' cognitive development in all curriculum areas. We trust it is important to create and favour a rich environment that awakes active learning and lets students engage in the way they fell more comfortable. At e-learning café we deliberate mix studying, social events and cultural activities.

Research and innovation are favored when art, science and humanities come together, [5] that's why the e-learning café is a place where cross disciplinary thinking is stimulated. By encouraging networking and the exploitation of technology we are confident students will be better prepared for the future, to experiment, to take risks and to innovate

\section{FINAL COMMENTS}

At the e-learning café the informal space allows students not only to study but also to acquire soft skills that will be important in their education path. In this paper we presented several activities that were conceived and implemented to attract students and develop these skills.

In the $21^{\text {st }}$ century, technology is present in every field of human activity. Technology has changed our perception of space and the ways we interact with space and with each other. At the e-learning café of the University of Porto, space design, technology and activities are added together to promote communication, collaboration, learning, entrepreneurship and innovation.

Having a space were all the areas of knowledge can be together, giving the opportunity for students to meet, share, discuss and enrich their experiences with others of different areas and with different experiences is what we have to offer to our students.

The first e-learning café of U.Porto was launched in 2008 and the results already obtained uncovered the potential of this concept to influence the inclusive education of citizens and their active role in society for contributing to the progress of their communities.

\section{REFERENCES}

[1] UP University of Porto. www.up.pt

[2] Malcolm B. "Learning Spaces" in Educating the Net Generation. Diana G. Oblinger and James L. Oblinger, eds. Boulder, Colo.: EDUCAUSE, 2005. http://www.educause.edu/Resources/EducatingtheNetGeneration/Lear ningSpaces/6072 (accessed May 11, 2012).

[3] Joint Information Systems Committee (JISC). Designing spaces for effective learning: A guide to 21 st century learning space design. Bristol, UK: JISC, 2006. http://www.jisc.ac.uk/uploaded_documents/JISClearningspaces.pdf (accessed May 11, 2012).

[4] Neto, P., Vieira, A., Vale, C., Ribeiro, L. 2007. E-Learning Café at the University of Porto: ICT Influence on Design of Social Learning Spaces, in 13th Congress of the European University Information Systems Organization. Grenoble, France.

[5] OWP/P Architects + VS Furniture + Bruce Mau; 2010, The Third Teacher: 79 Ways You Can Use Design to Transform Teaching \& Learning, Abrams. 